\title{
Teaching Hands-on Urban Forestry Health Assessment Using the Resistograph and the CTLA Method
}

\author{
David L. Kulhavy, Daniel R. Unger, Hans M. Williams, \& David R. Jamar \\ Arthur Temple College of Forestry and Agriculture \\ Stephen F. Austin State University \\ Box 6109, SFA Station \\ Nacogdoches, TX 75962, USA
}

Received: Jan. 29, 2015 Accepted: Feb. 27, 2015 Published: February 28, 2015

doi:10.5296/jse.v5i1.7150 URL: http://dx.doi.org/10.5296/jse.v5i1.7150

\begin{abstract}
Undergraduate students were instructed how to assess the health of 24 urban willow oak trees. Students received hands-on training using the Resistograph 400 on two sites: a depressional site and a well-drained site on the campus of Stephen F. Austin State University in an upper division Urban Forestry course. Students followed the instructed and prescribed method of drilling three holes at 120 degree intervals at 3.5 feet in height above ground in each oak tree. Tree condition data were recorded on paper strips and analyzed in laboratory for percent decay measured for each sample. The results were averaged for the three samples per tree and the percent of soundwood was determined. Resistograph data were then analyzed by the students using SAS ANOVA for the 24 trees within the two sites. Results indicted a significantly higher amount of decay on the depressional sites compared to the well-drained sites. Data collected using the standard CTLA tree health assessment method indicated willow oaks in depressional sites had a significantly lower condition rating based on six measured tree variables. This study demonstrated that incorporating intensive hands-on instruction within an undergraduate student's education increases retention rates, enhances their educational experience, and produces a more well-rounded urban forester.
\end{abstract}

Keywords: Resistograph, CTLA method, Hazard rating, Urban forestry 


\section{Introduction}

Hands-on instruction is extremely valuable in a science-based curriculum, not only for learning a specific task, but also for peaking a students' interest and offering valuable experience that could be used throughout their career. The Arthur Temple College of Forestry and Agriculture (ATCOFA) at Stephen F. Austin State University (SFASU) continually exposes undergraduates to career oriented projects and curriculum including outdoor labs, internships, temporary jobs and research opportunities within the college, and a six week field station to culminate the education (Unger, Kulhavy, Hung, and Zhang, 2014).Urban forestry is one of the degrees offered, and graduatesare sought after for positions as city foresters, consulting arborists, and utility foresters. As environmental awareness among the public continues to grow, more concern and respect is being given to the environment around us. With this awareness, there is also a need for someone to manage these sustainable resources in and around urban communities.

The urban forest is an important sustainable resource that provides ecological, social, and economic functions and benefits over time (Konijnendijk, Ricard, Kenney, and Randrup, 2006). While the urban forest continues to provide benefits, it also continues to deteriorate due to the unfavorable conditions in the urban environment. Trees in urban areas are generally not as healthy as their counterparts in rural areas due to the alteration of the ecosystem in municipal areas. Tree failure often leads to personal injury or property damage on both public and private land, and trees are regularly removed because they are considered an unacceptable risk and/or a legal liability (Mortimer and Kane, 2004). Because trees are living organisms, growing in varied environments, it is almost impossible to predict exactly when a tree will fail (Kane, Dennis, and Bloniarz, 2001). Urban foresters and arborists must learn to manage these hazards using science, technology, and sound observations which students within ATCOFA are exposed to on a daily basis. Among the many tools students within ATCOFA are exposed to include the Commercial Tree and Landscape Appraisal (CTLA) method and the Resistograph for assessing the health of urban trees.

Tree hazard and tree retention assessments assist arborists in knowing what is reasonable to retain and why, and to provide a more defensible basis for removal if needed (Dunster, 1996). Students studying forestry at SFASU are taught that methods exist for measuring tree hazards which allow arborists and urban foresters to make informed management decisions concerning the urban forest. The most common and widely used method of establishing the value and condition of large trees worldwide is through the use of formulas (Watson, 2002). Through research, experience, observation, and common sense, arborists and urban foresters have identified many risk factors that predispose trees to failure (Kane, Dennis, and, Bloniarz, 2001). The CTLA method was built upon this research, experience, and observations, and was adopted by the International Society of Arboriculture (ISA) in 1951. The main use of this formula is for estimating the compensatory value of trees (Nowak, 1993). Students within ATCOFA are taught that the CTLA formula allows the assessor to examine any tree thoroughly for either monetary purposes or safety concerns. The formula establishes an initial value based primarily on size, and then adjusts this value (usually down if less than perfect) for factors such as condition (vigor, structure, health, etc.), location (setting, real estate value, 
function, visibility, etc.), species quality, and special situations (historic significance, etc.) (Watson, 2002).

The Resistograph, which students are introduced to in the second half of their undergraduate career, was designed for practical examination of standing trees, structural timbers and poles (Winistorfer, Xli, and Wimmer, 1995). The Resistograph has a rechargeable battery, a printer with pressure sensitive paper and a control for hardness of wood. The three health readings from the Resistograph are based on the drilling resistance of a 1/8 inch drill drilled into the tree at a constant speed. Amplitude readings of resistance are recorded in relation to the density of the wood measured. As a rot column is encountered, resistance drops to zero and this is recorded and measured (Mattheck, Bethge, and Albrecht, 1997) on paper strip charts that indicate the location of decay and can be measured or plotted to determine the extent of the decay. Students are taught that the resistance of the wood changes the rotation speed of the drill resistance to the torque of the penetrating drilling bit (Rinn, Schweingruber, and Schar, 1966). The Resistograph is successful in the quantitative assessment of decay in trees and can reduce unnecessary removal of trees and also assist in removal of hazardous trees when combined with a hazard rating or expert system (Johnstone, Ades, Moore, and Smith, 2007; Johnstone, Moore, Tausz, andNicolas, 2010).

\section{Study Site}

During a spring semester students in a senior Urban Forestry course examined 24 willow oaks (Quercus phellosL.) on the campus of SFASU (Figure 1). Willow oak was chosen due to noticeable differences in trees located in a depressional area and those found on well drained 


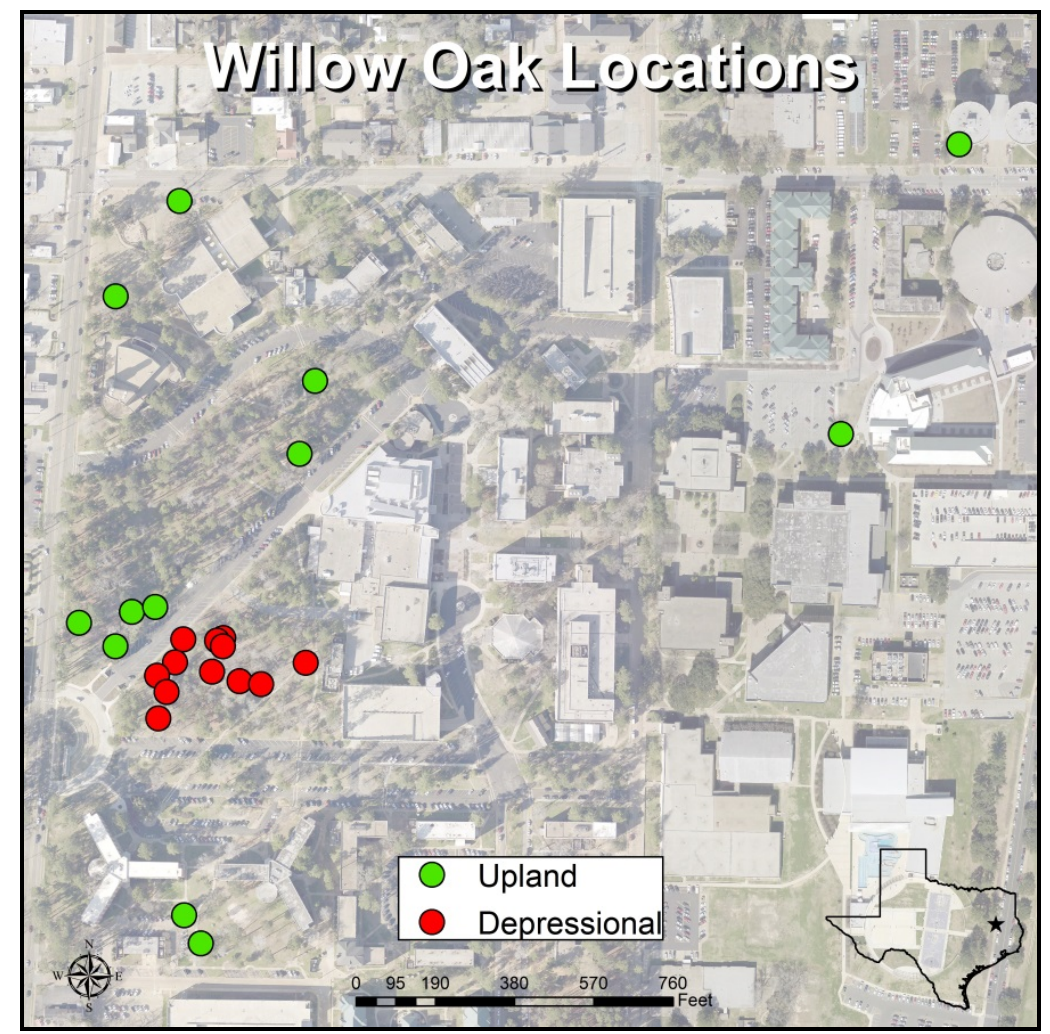

Figure 1. Location of 24 willow oaks, Quercus phellos, on the campus of Stephen F. Austin State University, Nacogdoches, Texas

locations throughout campus. The oaks were divided into two groups; 12 in depressions and 12 on uplands on the campus. Willow oaks in the depression group were located adjacent to the Baker Pattillo Student Center.Of the 12 upland willow oaks, six were adjacent to the depressional area in Vista Woods, two were near the corner of North St. and E. College St., two were on the south side of Griffith Hall, one was located in front of Steen Hall, and one located at the north side of the library. These 12 upland willow oaks were all located on mesic or well-drained sites and grouped together for the study. Undergraduate students located each willow oak with a Juno Handheld GPS unit and entered the location data into an ArcGIS 10.1 GIS database in the ATCOFA GIS laboratory for spatial analysis and visual display.

\section{Methods}

Students were taught how to evaluate the 24 willow oaks with the CTLA method (CTLA, 2000) including species class, location, value and condition. In addition, students were taught how to use the Resistograph to evaluate tree condition with the overall study objective of having students evaluate the presence of internal decay using the Resistograph and compare the findings with overall tree health of the 24 willow oaks on campus using the CTLA method. The six measures of tree condition including: trunk, crown condition, insects and disease, expected longevity, crown structure and growth, were the main focus of the assessment.An examination of the willow oaks was completed by undergraduate students 
using the CTLA method (CTLA, 2000) and a compositecondition score for each tree was compiled as percent condition calculated by dividing the assessed score by the maximum score of 26 (Figures 2 and 3).

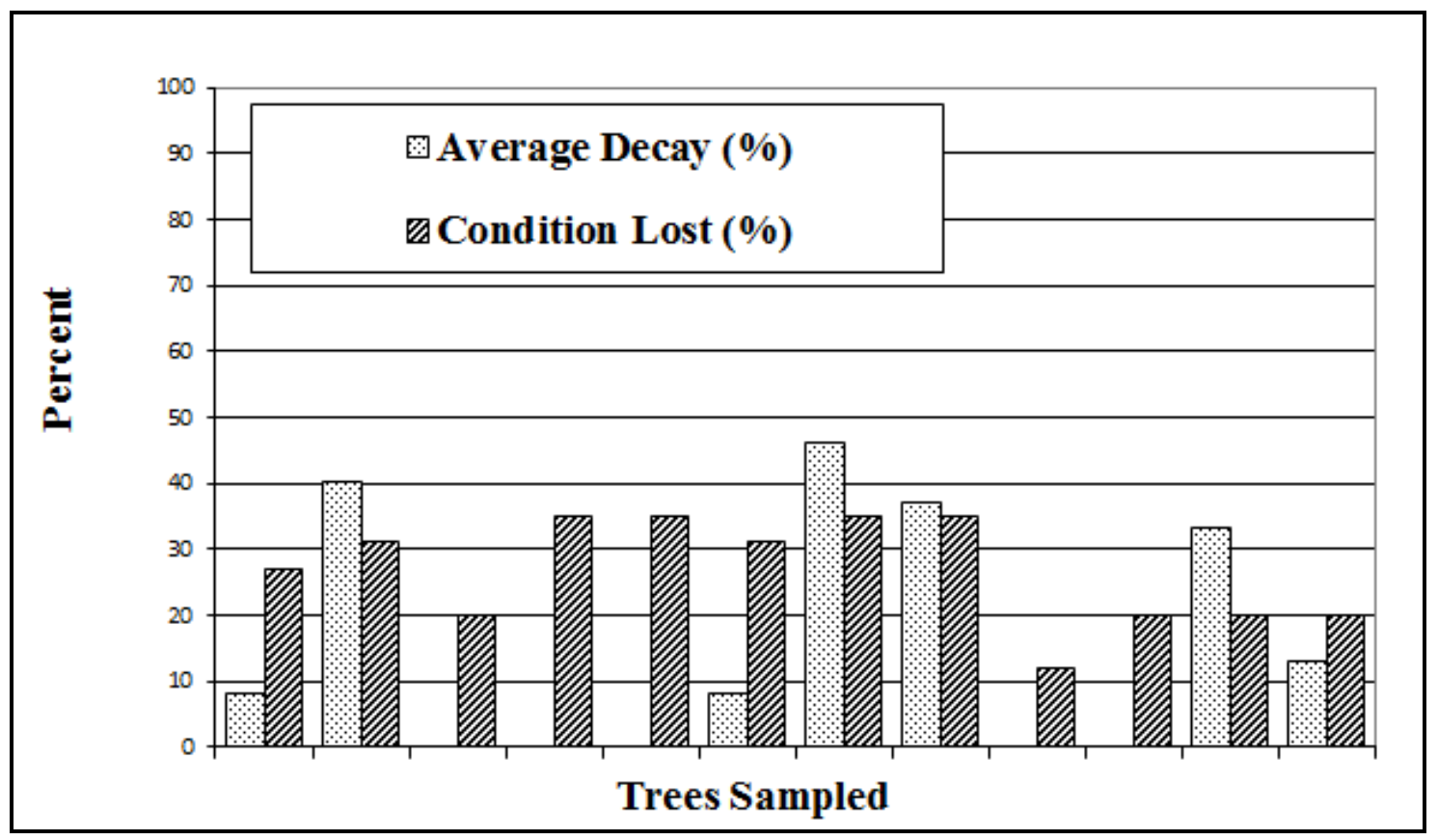

Figure 2. Graphical representation of the correlation between the average decay and low condition rating for 12 willow oak on well drained sites

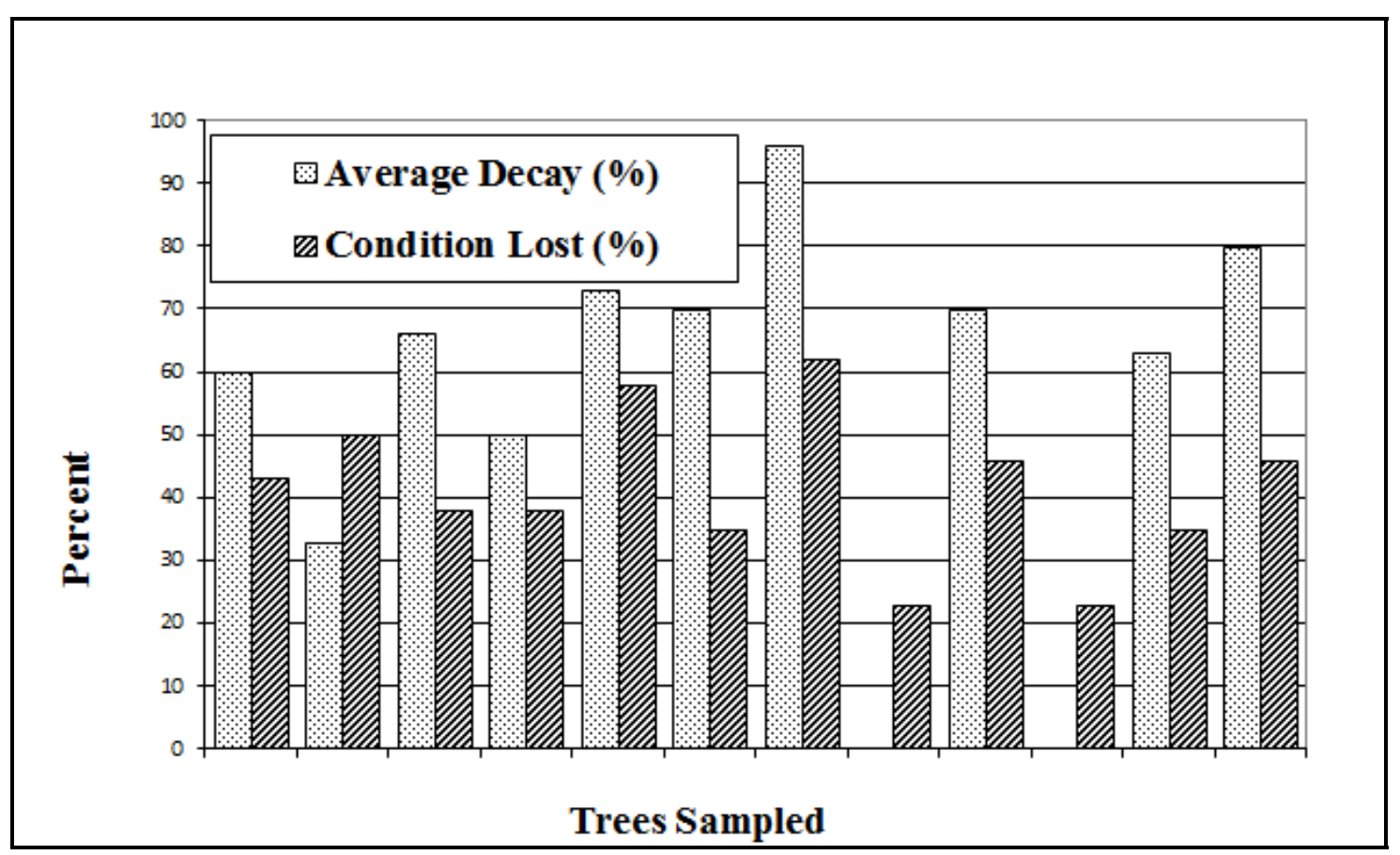

Figure 3. Graphical representation of the correlation between the average decay and low condition rating for 12 willow oak on depressional sites

The undergraduate students were taught how to use the Resistograph to detect and record the amount, if any, of decay present in each tree (Figure 4). The students were instructed via 


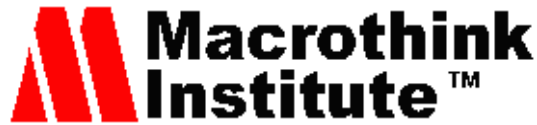

Journal of Studies in Education

ISSN 2162-6952

2015, Vol. 5, No. 1

hands-on instruction to take three samples per tree at sequential 120 degree angles (Ukrainetz and O'Neill, 2010) and directed towards the center of the tree on 24 willow oaks (Figure 5). Only one sample was recorded per tree for 2 trees with a diameter of $<20$ inches, which was considered adequate for evaluating smaller diameter trees.

Students were shown how to space drilling locations evenly around the trunk of each tree at a height of 3.5 feet above ground level. The height ( 3.5 feet) of the measurement was chosen as a good location for detecting decay columns stemming from the roots since approximately $70 \%$ of tree failures occur in the trunk or roots. The lower height was used so the data being recorded could be easily viewed as the drilling needle progressed. Each hole was drilled to a depth of 14.75 inches on trees with a diameter of $>29.5$ inches. Trees with a diameter of $<$ 29.5 inches were sampled to a depth equal to half of the diameter. The recording paper was removed after each drilling and labeled by date, species, tree number and site (Figure 6). After all trees were completed, students analyzed the data to evaluate the average amount of soundwood in each tree.

Students interpreted the results based on the wax paper reading, a print out of the resistograph measurements obtained in the field, and the average shell thickness (soundwood) was obtained. The shell is considered the area of soundwood surrounding a decayed area and an optimum thickness $\geq 1$ inch for every 6 inches of stem diameter. The students were taught that the average shell thickness needs to be multiplied by 2 to represent diameter, and then divided by

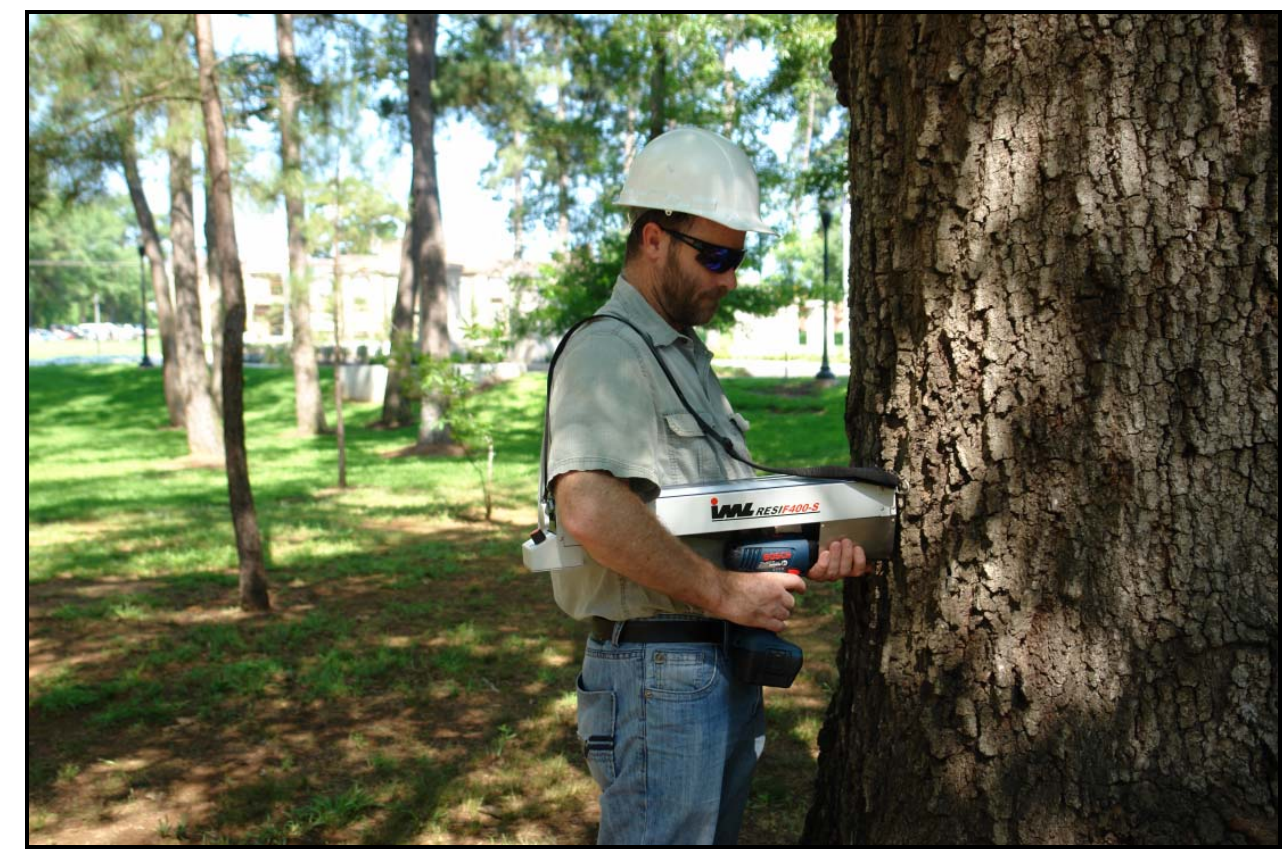

Figure 4. Graduate student demonstrating to undergraduate students how to take resistance measurements using a Resistograph 


\section{Macrothink}

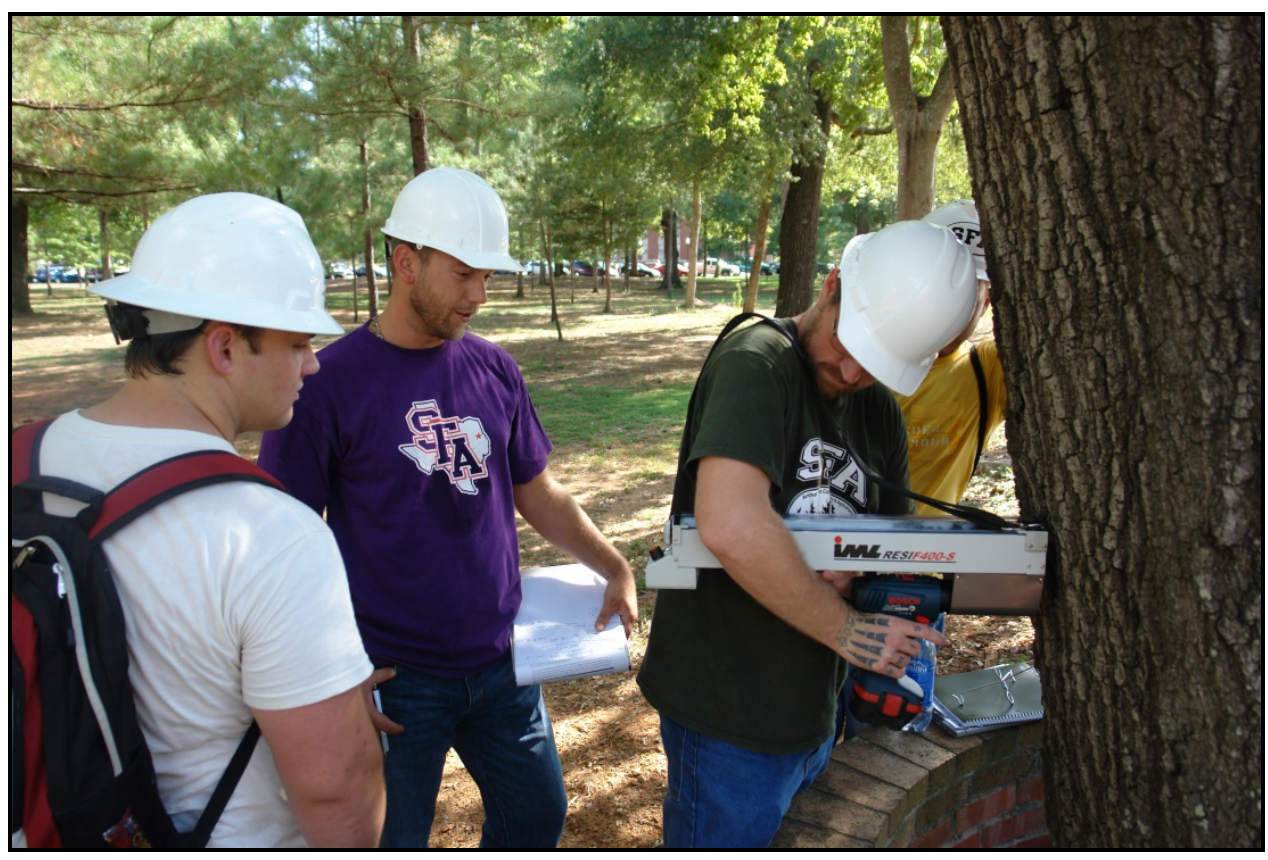

Figure 5. Undergraduate students taking resistance measurements after receiving interactive instruction on how to use a Resistograph

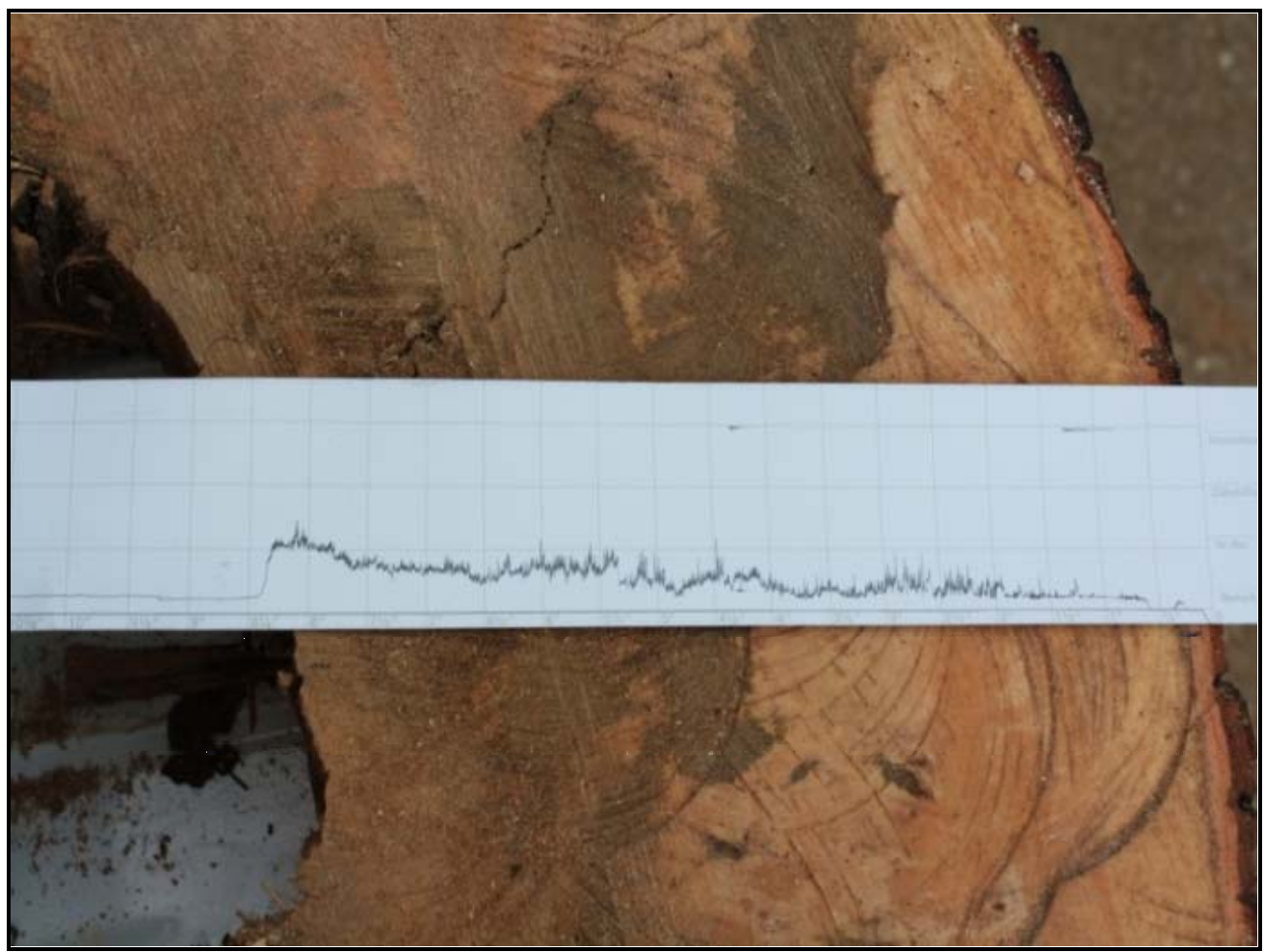

Figure 6. Sample of Resistograph reading on waxed sensitive paper showing normal resistance until contacting the hollow area inside a tree on the left side of the image

the actual diameter taken at 3.5 feet. From this the students obtained an average percentage of soundwood. Students then entered the results into SAS 9.2 and ran an Analysis of Variance (ANOVA) to obtain statistical variations or similarities between the CTLA method and the Resistograph results. 


\section{Results}

The students used an analysis of covariance to examine differences in the proportion (\%) of soundwood in willow oaks located in well-drained or depressional sites on the campus of SFASU. Students were taught to use Condition (\%) as the covariate, which was calculated as the proportion of six hazard tree scoring values (i.e., trunk, growth, structure, crown, life expectancy, and insects/disease). If differences $(P<0.05)$ occurred, students were shown how to use the least squares mean separation to examine the direction and magnitude of the variancemore closely.

Overall, students discovered that the amount ( $\%)$ of soundwood varied $(F=19.02 ; \mathrm{df}=2,21$; $P<0.001)$ between willow oaks located in well-drained and depressional sites. Willow oaks in well-drained soils (mean $=83.5 \%$ ) averaged $>35 \%$ greater soundwood than those in depressional sites $($ mean $=47.5 \%)$. However, when variation in willow oak soundwood by location was examined with condition as a covariate, condition (\%) drove the analyses, and was more important $(F=15.92 ; \mathrm{df}=1,21 ; P<0.001)$ than site $(F=1.90 ; \mathrm{df}=1,21 ; P=$ $0.183)$ in explaining differences in soundwood in willow oaks. Students found the average condition rating was $58.6 \%(\min =38, \max =77)$ for the depressional area and $73.3 \%(\mathrm{~min}=$ 65 , $\max =88$ ) for the well-drained sites. In other words, there was a strong correlation between condition and the amount of soundwood (wood free from defects). Simply, trees in better condition had more soundwood, whereas trees in poorer condition had less soundwood. Condition rather than location appeared to be the most important driver of proportion soundwood in willow oaks on the SFASU campus. Further investigation will be needed to determine the factors influencing the poor condition and lack of soundwood in the depressional area. These factors could include soil compaction, poor drainage, and low site productivity.

\section{Project Outcomes and Benefits}

Students discovered that the results indicated a significantly higher amount of decay on the depressional sites compared to the well-drained sites. Data collected using the CTLA method indicated willow oaks in depressional sites had a significantly lower condition rating based on six measured tree variables. Kulhavy, Wu, Unger, Hung, and Sun (2014) found the same relationship comparing campus and park trees in Nacogdoches, Texas. The ANOVA indicated that the internal condition was strongly related to the external condition ratings for the willow oaks. The measurements were consistent among students on the same trees and the students discovered the Resistograph easy to use, producing repeatable results. As each willow oak was sampled, percent decay was measured. The higher incidence of decay was visually evident and the statistical analysis confirmed both a site relationship and a relation to tree condition.

Integrating the Resistograph in an urban forestry course is important because of ease of use with minimal instruction. Instruction included loading of the wax pressure sensitive paper and proper insertion of the drill bit. Two settings for tension are for hardwood (tension setting 2) conifers, and other softwoods (tension setting 1). The length of the drill bit (14.75 inches) allows for diagnoses of oaks up to 29.5 inches in diameter. Students were shown that care 
was needed when a decay pocket was detected to slow down drilling until the bit enters soundwood to avoid breaking the bit. Hands-on instruction emphasized that the Resistograph is portable and uses rechargeable batteries that are easy to change in the field.

When using the Resistograph, concepts of urban forestry were easy to teach including the concepts of hazard trees and tree health that was expanded from the CTLA and the Coder (1996) method of tree hazard assessment. When taking the Resistograph sample, the location of the oak for surrounding targets was assessed including distance to cars, paths and walkways and buildings. Oaks in the depressional sites near sidewalks and cars were considered higher risk and discussed for potential removal. Oaks with over 70 percent decay were discussed for removal based on the Wagener's formula of strength loss (in conifers). In our data, five of the willow oaks sampled had over 70 percent decay and were in the hazard zone for removal based on their diameter (Coder, 1989). With tree diameter ranging from 21 to 38 inches as measured 4.5 feet above ground level, strength loss needs to be above 44 percent to be considered hazardous. Using these guidelines, two of the willow oaks fall into this category.

Bartlett Tree Research Laboratories accepts the 33 percent tree strength loss as a hazard tree threshold, but uses 20 percent in the presence of other defects (Fraedrich, 1999). Students assessing tree health using Barlett (Smiley and Fraedrich, 1993; Fraedrich, 1999), two trees meet the threshold, but uses 20 percent when other defects or severe stresses are present an additional tree would be at hazard. However, condition will continue to decrease in the area and the willow oaks will decline. Management of willow oaks in the depressional sites includes recommendation of removal of three trees; continued evaluation following storm and wind damage (such as Hurricane Rita and Hurricane Ike that impacted SFASU in 2005 and 2008). Due to the loss of structure of these trees, the students found that willow oak is not recommended in the depression site. On the well-drained site, none of the willow oak meets the threshold for removal. This underlies the importance of site in evaluation of the urban forest and its integration with a forestry curriculum.

Based on the instructors observational data students learned that the use of the condition rating of the willow oaks using the CTLA method points to loss of structure on the depressional sites. The internal structure of the willow oaks measured by the students at 3.5 feet above ground with the Resistograph indicated considerable decay and evaluation of future management. The ease of use of the Resistograph combined with hazard and risk rating systems of a small number of oaks (a total of 24) proved to be a valuable teaching method that could be enforced later via the collection of student perception data. Overall, the students learned that understanding the integration of hands-on methods of willow oak health evaluation reinforced their understand of the ecological function of natural systems, learned valuable analytical skills, and understood more thoroughly the importance of managing forests for human use and enjoyment which represent three high performance and high importance variables for producing society-ready foresters with ATCOFA (Bullard, Coble, Coble, Darville, Rogers, and Stephens Williams, 2014). 


\section{References}

Bullard, S., Coble, D., Coble, T., Darville, R., \& Stephen-Williams, P. (2014). Producing 'Society-ready' Foresters: A research-based process to revise the Bachelor of Science in Forestry Curriculum at Stephen F. Austin State University. Arthur Temple College of Forestry and Agriculture, Stephen F. Austin State University, Nacogdoches, Texas, ATCOFA Monograph 1-2014.

Coder, K. D. (1989). Should you or shouldn't you fill tree hollows? Grounds Maintenance, 24, 68-70, 98-100.

Coder, K. D. (1996). Tree risk management and hazard assessment: A general overview.University of Georgia, School of Forest Resources, Ext. Pub. For. 96-033.

CTLA. 2000. Guide for plant appraisal. 9th edition. Champaign, Illinois: International Society of Arboriculture.

Fraedrich, B. R. (1999).Tree risk management-hazard trees.Charlotte, North Carolina: Bartlett Tree Research Laboratories.

Johnstone, D. M., Ades, P. K., Moore, G. M., \& Smith, I. W. (2007). Predicting wood decay in eucalypts using an expert system and the IML-Resistograph drill. Arboriculture and Urban Forestry, 33, 76-82.

Johnstone, D., Moore, G., Tausz, M., \&Nicolas, M. (2010). The measurement of wood decay in landscape trees. Arboriculture and Urban Forestry, 36, 121-127.

Kane, B., Dennis, R., \&Bloniarz, D. V. (2001). Comparing formulae that assess strength loss due to decay in trees. Journal of Arboriculture, 27, 78-87.

Konijnendijk, C. C., Ricard, R. M.,Kenney, A,\&Randrup, T. B. (2006). Defining urban forestry-A comparative perspective of North America and Europe. Urban Forestry and Urban Greening, 4, 93-103. http://dx.doi.org/10.1016/j.ufug.2005.11.003

Kulhavy, D. L., Wu, D., Unger, D. R., Hung, I-K. \&Sun, J. H. (2014). Comparison of tree condition and value for city parks and Stephen F. Austin State University in Nacogdoches, Texas, U. S. Arboriculture \& Urban Forestry, 40, 165-177.

Mattheck, C, K. Bethge, K., \&Albrecht, W. (1997). How to read the results of Resistograph M. Arboriculture Journal, 21, 331-346. http://dx.doi.org/10.1080/03071375.1997.9747179

Mortimer, M. J., \&Kane, B. (2004). Risk tree liability in the United States: Uncertain risks for owners and professionals. Urban Forestry and Urban Greening, 2, 297-302. http://dx.doi.org/10.1078/1618-8667-00032

Nowak, D.J. (1993). Compensatory value of an urban forest: An application of the tree-value formula. Journal of Arboriculture, 19, 173-177. 


\section{Macrothink}

Journal of Studies in Education

ISSN 2162-6952 2015, Vol. 5, No. 1

Rinn, F., Schweingruber, F. H., \& Schar, E. (1996). Resistograph and X-ray density charts of wood: comparative evaluation of drill resistance profiles and X-ray density charts of different wood species. Holzforschung, 50, 303-311. http://dx.doi.org/10.1515/hfsg.1996.50.4.303

Smiley, E. T., \& Fraedrich, B. R. (1993). Hazardous tree evaluation and management. Charlotte, North Carolina: Bartlett Tree Research Laboratories.

Ukrainetz, N. K., \&O’Neill, G. A.(2010). An analysis of sensitivities contributing measurement error to Resistograph values. Canadian Journal of Forest Research, 40, 806-811.http://dx.doi.org/10.1139/X10-019

Unger, D. R., Kulhavy, D. L., Hung, I., \& Zhang, Y. (2014). Quantifying natural resources using field-based instruction and hands-on applications. Journal of Studies in Education, 4, 1-14. http://dx.doi.org/10.5296/jse.v4i2.5309

Watson, G. (2002). Comparing formula methods of tree appraisal. Journal of Arboriculture, 28, 11-18.

Winistorfer, P.M., Xli, W., \&Wimmer, R. (1995). Application of drill resistance technique for density profile measurement in wood composite panels. Forest Products Journal, 45, $50-53$. 